\title{
Efektivitas Penggunaan Akun Instagram @Larissacenter Sebagai Media Beriklan Larissa Aesthetic Center Berdasarkan Metode Customer Response Index (CRI)
}

\author{
Astri Wulandari ${ }^{1}$ dan Nur Latifah Lutfiyati*2 \\ ${ }^{1,2}$ Universitas Mercu Buana Yogyakarta \\ Email: astri@mercubuana-yogya.ac.id,nlutfiyati@gmail.com* \\ *corresponding author
}

Keywords:

Advertising

Social Media

Instagram

CRI

\begin{abstract}
Social media has become opium and created its own "world" for its users. Like a window, netizens can monitor, view and find out information, news, or events that are currently viral through social media. Instagram is one of the popular applications to show existence through social media. The phenomenon of the large number of active Instagram users in Indonesia contains the 3rd position in the world. The ease of access to Instagram is now being seen by the company to advertise its products and services. This study aims to find out and identify the advertising of Larissa Aesthetic Center through an Instagram account on skin care users and beauty clinics in Yogyakarta, women and aged 17-35 years. This type of research is quantitative descriptive. The sample in this study were 100 people. The sample in this study uses the technique of determining samples for an infinite number of sizes. The response element in the Customer Response Index (CRI) is conscious (awareness), understanding (understanding), interest (interest), intention (intention to buy), and action (action). Based on the results of a simple tabulation and analysis of the average score by the CRI method on media advertisements on Instagram social media using advertisements on Instagram social media included in the category of "quite effective" with a percentage of $52.76 \%$ because respondents have made purchases of Larissa Aesthetic products Center advertised on Instagram @ larissacenter account with the results obtained from CRI calculations is aware of the percentage of $92 \%$, understanding with a percentage of $8034 \%$, interest with a percentage of $78.38 \%$, intention with a percentage of $96,55 \%$, and actions with a percentage of $94.34 \%$.
\end{abstract}

\begin{abstract}
ABSTRAK
Media sosial telah menjadi sebuah candu dan menciptakan "dunia" sendiri bagi para penggunanya. Bak sebuah jendela, netizen dapat memantau, melihat serta mengetahui informasi, berita, atau kejadian yang sedang viral lewat media sosial. Instagram merupakan salah satu aplikasi yang digemari untuk menunjukkan eksistensi lewat media sosial. Fenomena terhadap tingginya pengguna aktif instagram di Indonesia telah menempati posisi ke-3 didunia. Kemudahan dalam mengakses instagram saat ini mulai dilirik oleh perusahaan untuk mengiklankan produk dan jasanya. Penelitian ini bertujuan untuk mengetahui dan mengidentifikasi efektivitas iklan Larissa Aesthetic Center melalui akun instagram pada pengguna skincare dan klinik kecantikan di Yogyakarta, perempuan dan berusia 17-35 tahun. Tipe penelitian ini adalah deskriptif kuantitatif. Sampel dalam penelitian ini adalah 100 orang. Sample dalam penelitian ini menggunakan teknik penentuan sample untuk ukuran populasi tidak terhingga. Elemen respon dalam Customer Response Index (CRI) adalah aware (kesadaran), comprehend (pemahaman), interest (ketertarikan), intention (niat untuk membeli), dan action (tindakan). Berdasarkan hasil analisis tabulasi sederhana dan analisis skor rata - rata
\end{abstract}


dengan metode CRI pada iklan Larissa di media sosial instagram menunjukan bahwa iklan Larissa pada media sosial instagram termasuk dalam kategori “cukup efektif" dengan prosentase sebesar 52,76\% karena responden telah sampai pada tahapan melakukan pembelian terhadap produk Larissa Aesthetic

Kata Kunci: Iklan

Media Sosial

Instagram

CRI Center yang diiklankan pada akun Instagram @larissacenter dengan hasil yang didapat dari perhitungan CRI adalah aware dengan prosentase sebesar 92\%, comprehend dengan prosentase sebesar $8034 \%$, interest dengan prosentase sebesar 78,38\%, intentions dengan prosentase sebesar $96,55 \%$, dan action dengan prosentase sebesar $94,34 \%$.

Copyright (C) 2018 Channel Jurnal Komunikasi. All right reserved.

\section{PENDAHULUAN}

Persaingan pasar menjadi semakin ketat dengan adanya keterbukaan akses informasi sehingga membuat konsumen lebih selektif dalam menentukan keputusannya, sehingga produsen harus memikirkan cara promosi yang unik untuk menarik perhatian konsumen contohnya seperti menentukan media periklanan yang tepat menyasar konsumen. Iklan yang efektif dapat digunakan oleh perusahaan atau produsen dan biro iklan untuk mempengaruhi persepsi dan preferensi konsumen terhadap berbagai merek produk di pasar yang tentu menjadi salah satu faktor penting dalam proses pengambilan keputusan oleh konsumen dalam memilih suatu produk (action). Internet merupakan salah satu media yang telah menjadi candu dan sangat memberikan kemudahan bagi semua orang dalam memenuhi kebutuhannya. Kita seolaholah dimanjakan oleh internet dan seperti tidak bisa memandang sesuatu yang jauh tanpa adanya internet. Apalagi sekarang dengan maraknya pertumbuhan situs jejaring sosial di dunia maya, media social networking ini juga telah dilirik oleh para konsumen e-commerce untuk memasarkan produk yang mereka jual. Sudah banyak perusahaan yang merambah internet sebagai salah satu alternatif untuk beriklan serta lebih efektif untuk menjangkau konsumennya dengan menggunakan social media seperti instagram. Media sosial adalah teknologi berbasis internet yang memfasilitasi percakapan. Secara garis besar, media sosial dapat di kelompokkan menjadi; (1) egocentric sites (memungkinkan pengguna untuk membuat profil ), (2) community sites ( membangun komunitas di dunia virtual), (3) opportunistic sites (memfasilitasi bisnis), (4) passion-centric sites (berhubungan dengan sesama peminat), dan (5) media sharing sites (berbagi konten gambar, audio dan video) (Tjiptono, $2015: 394)$.

Menurut hasil survey WeAreSocial.net dan Hootsuite, instagram merupakan platform media sosial dengan jumlah pengguna terbanyak ke-7 di dunia. Selain sebagai jejaring sosial untuk berbagi foto, instagram digunakan untuk memasarkan produk bisnis karena biaya beriklan yang terjangkau dan dapat meraih konsumen lebih luas. Total pengguna instagram di dunia mencapai angka 800 juta pada bulan Januari 2018.

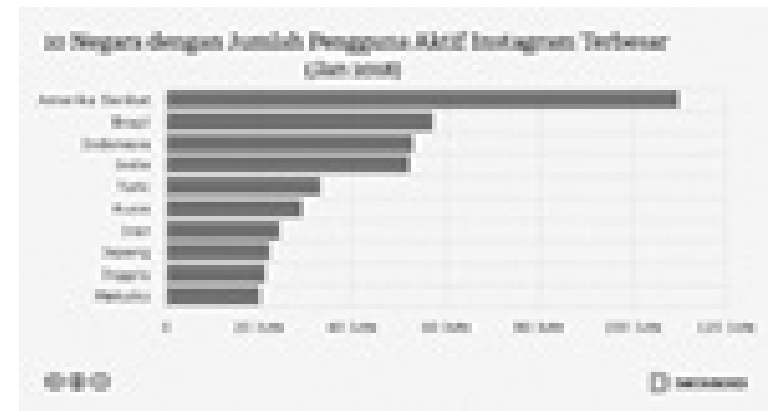

Gambar 1. Pengguna Aktif Instagram Terbesar Januari 2018

Salah satu perusahaan yang turut menggunakan media sosial instagram sebagai salah satu sarana menggencarkan iklan produknya adalah Larissa Aesthetic Center. Larissa Aesthetic Center didirikan pada 11 Juni 1984 oleh R.Ngt. Poedji Lirnawati berbekal ilmu yang diperoleh dari Key Brown Beauty School di Los Angeles, USA dan juga beberapa perguruan tinggi khususnya dibidang ilmu kosmetologi di Jerman, Perancis, Jepang, Hongkong, Singapore dan didorong oleh sebuah keinginan untuk memberikan pelayanan dibidang perawatan kulit dan rambut yang aman, sehat dan tanpa efek samping. Konsep yang dikembangkan oleh Larissa Aesthetic Center adalah perawatan kulit dan rambut dengan menggunakan bahan - bahan alami seperti buah, sayuran, umbi, batang dan akar sesuai dengan tagline konsep "back to nature” yang dimiliki Larissa Aesthetic Center. Terhitung sejak tanggal 2 Juni 1998 Larissa Aesthetic Center sudah memiliki sertifikat merek dari Departemen Hukum dan Perundang - Undangan Republik Indonesia Direktorat Jendral Hak Atas Kekayaan Intelektual. Larissa Aesthetic Center mendapatkan penghargaan "Merk Terbaik kategori Skincare di Jogja" dalam Solo Best Brand Index - Jogja Best Brand Index 2015 (Larissa, 2018; larissa.co.id/about, diakses tanggal 22 Mei 2018). 
Klinik kecantikan dan skincare terutama yang berada di Yogyakarta pun gencar melakukan kegiatan promosi di instagram karena dianggap bisa menjadi media promosi yang cukup efektif terutama untuk menjangkau target sasaran produk yaitu anak muda atau mereka yang berada di usia produktif. Salah satu cara untuk mengukur efektivitas iklan adalah dengan metode Customer Response Index (CRI). CRI adalah angka untuk menunjukkan efektivitas iklan dengan melihat respon audiens. CRI merupakan hasil perkalian antara angka awareness (kesadaran), comprehend (pemahaman), interest (ketertarikan), intentions (niat), dan action (tindakan) yang diberikan audiens setelah melihat iklan tersebut.

Penelitian terdahulu dengan menggunakan metode CRI dengan judul Efektivitas Pesan Iklan Televisi Tresemme Menggunakan Customer Response Index (CRI) Pada Perempuan di Surabaya oleh Tania Yosephine Aiwan. Hasil dari penelitian ini menghasilkan kesimpulan bahwa pesan iklan Tresemme adalah efektif. Penelitian terdahulu lainnya dengan judul Mengukur Efektivitas Tagline Iklan Televisi Minuman Ringan The Botol Sosro Dengan Metode Customer Response Index (CRI) oleh Gesty Ernestivita yang menunjukkan bahwa menurut analisis CRI tagline iklan The Botol Sosro versi "apapun makanannya minumnya The Botol Sosro" dinilai sangat efektif karena hasil penelitian menunjukkan penilaian hampir $100 \%$.

\section{TINJAUAN PUSTAKA}

\section{a. Efektivitas Iklan}

Pesan iklan yang efektif akan memenuhi keinginan pengiklan dan audiensi sasaran akan memberikan respon sebagaimana yang diinginkan oleh pengiklan. Dampak yang diharapkan itu biasanya secara formal disebut tujuan, yaitu pernyataan tujuan atau hasil yang dapat diukur sebagaimana yang diharapkan oleh pengiklan. Iklan sukses apabila mencapai tujuannya (Moriaty, et al., $2011: 30$ ).

\section{b. New Media and Social Media}

New Media terdiri dari 2 kata yaitu new dan media. New yang berarti berarti baru dan media yang berarti perantara. Jadi new media merupakan sarana perantara yang baru. Baru dalam arti disini di lihat dari segi waktu, manfaat, produksi, dan distribusinya serta terbentuk dari interaksi antar manusia dengan computer dan internet khususnya termasuk didalamnya sebagai media komunikasi adalah web, blog, online sosial network, online forum, dsb (Irianta, 2005).

New media telah tumbuh dan berkembang seiring perkembangan teknologi komunikasi dan informasi dan masyarakat mengikuti arus perkembangan tersebut membawa dampak baik dan buruk di setiap aspeknya. John Vivian dalam Cyber Media menjelaskan keberadaan media baru seperti internet melampaui pola - pola penyebaran pesan media tradisional, hal ini didukung dengan adanya sifat internet yang bisa berinteraksi, menggaburkan batas geografis, kapasitas interaksi, dan hal yang penting adalah dapat dilakukan secara real time (Narullah, 2013 : 17).

\section{c. CRI (Customer Response Index)}

Customer Response Index adalah alat analisis yang digunakan untuk mengetahui respon konsumen pada suatu periode waktu tertentu kampanye iklan suatu merek, dalam bentuk presentase, respon konsumen dalam kuesioner. Merupakan perkalian awareness, comprehend, interest, intention, action (Durianto, 2003 : 10).

CRI menghasilkan presentase efektivitas iklan dari berbagai tingkatan. Berbagai tingkatan efektivitas iklan dapat diukur melalui tahap - tahap CRI (Best, 2012 : 247). Berikut adalah tahapan - tahapan CRI beserta metode perhitungan prosentasenya : (1) Unawareness (2) No Comprehend = Awareness x No Comprehend (3) No Interest = Awareness $\mathrm{x}$ No Interest (4) No Intentions $=$ Awareness $\mathrm{x}$ Comprehend $\mathrm{x}$ Interest $\mathrm{x}$ No Intentions (5) No Action $=$ Awareness $\mathrm{x}$ Comprehend $\mathrm{x}$ Interest $\mathrm{x}$ Intentionss $\mathrm{x}$ No Action (6) Action = Awareness $\mathrm{x}$ Comprehend $\mathrm{x}$ Interest $\mathrm{x}$ Intentions $\mathrm{x}$ Action.

\section{METODE PENELITIAN}

Jenis penelitian yang digunakan dalam penelitian ini adalah penelitian kuantitatif deskriptif. Efektivitas iklan dapat diukur menggunakan metode CRI (Customer Respon Index). CRI (Customer Response Index) merupakan hasil perkalian antara awareness (kesadaran), comprehend (pemahaman konsumen), interest (ketertarikan), intentions (maksud untuk membeli) dan action (bertindak membeli). CRI menampilkan proses akhir berupa pembelian yang berawal dari munculnya kesadaran akan sebuah iklan.

Rata-rata penilaian responden terhadap efektivitas iklan Larissa Aesthetic Center @1arissacenter di Instagram dengan rentang skala nilai; (1) 1,00 - 33,00 : Iklan Larissa Aesthetic Center@larissacenter kurang efektif (2) 34,00 66,00 : Iklan Larissa Aesthetic Center @larissacenter cukup efektif (3) 67,00 - 100,00 : Iklan Larissa Aesthetic Center @larissacenter sangat efektif. 


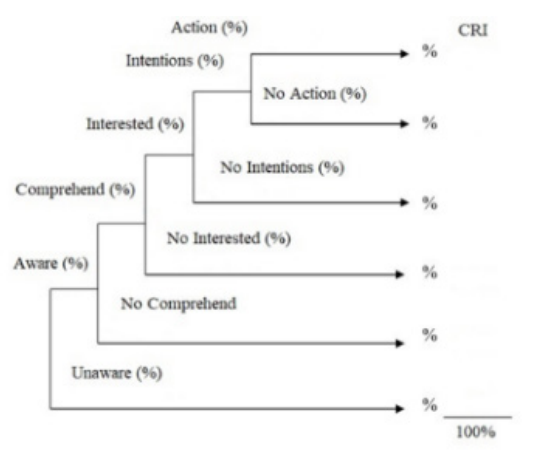

Gambar 2. Bagan Model CRI

\section{HASIL DAN ANALISIS}

Larissa Aesthetic Center mulai menggunakan instagram sejak tahun 2016 ketika pembukaan gerai pertama Larissa Aesthetic Center di Surabaya. Peralihan media beriklan dari media beriklan konvensional ke media sosial dilakukan dengan bertahap untuk mengetahui respon konsumen.

Pada awal penggunaan instagram Larissa Aesthetic Center melakukan sosialisasi kepada konsumen baik melalui customer service di gerainya maupun dengan memperbanyak iklan instagram atau instagram adds. Larissa mulai beralih mengiklankan produk dan jasanya melalui media sosial terutama instagram dikarenakan Larissa Aesthetic Center ingin menyesuaikan segmentasi produk mereka yakni pelajar, mahasiswa, PNS dan pegawai bank dan untuk mengiklankan produk secara efektif dan efisien.

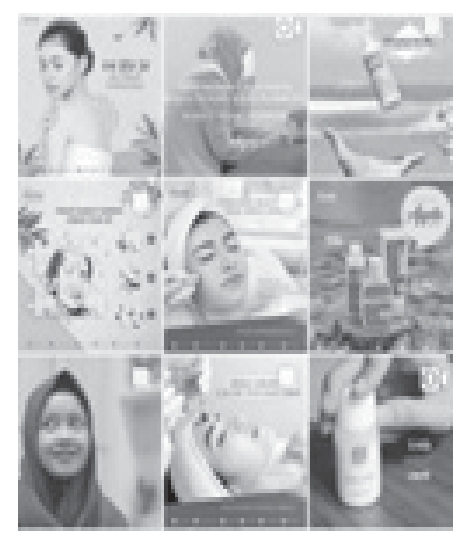

Gambar 3. Tampilan Feeds Instagram @1arissacenter

Penelitian di lakukan pada periode Maret-Mei 2018. Berdasar pada observasi dan pengamatan pada bulan Maret 2018 Larissa Aesthetic Center dengan akun @larissacenter meng-upload 20 konten dalam akun Instagram mereka, dan 20 konten untuk bulan April 2018 serta bulan Mei sebanyak 28 konten.

Feed instagram Larissa Aesthetic Center memiliki tiga konten disetiap sisinya seperti yang ditunjukkan pada gambar 2. Tiga konten yang telah di posting tersebut memuat tiga poin utama yakni; (1) informasi tentang produk Larissa Aesthetic Center, (2) games, (3) giveaway, kemudian fun facts berada disebelah kiri feeds instagram, selain itu di bagian tengah merupakan informasi mengenai konten produk perawatan yang ditawarkan Larissa Aesthetic Center sedangkan bagian kanan feeds merupakan konten mengenai produk dari Larissa Aesthetic Center beserta kegunaannya.

Pengaturan tiga konten utama ini untuk memudahkan user instagram melihat tampilan instagram Larissa Aesthetic Center dan membuat konsumen lebih mudah untuk memperoleh informasi terkait produk. Pengaturan ini dimulai sejak bulan Februari 2018 sebagai maintenance dari akun instagram Larissa Aesthetic Center.

Larissa juga menggunakan iklan yaitu dengan memanfaatkan instagram adds untuk meningkatkan lagi segmentasi pasar dan tingkat penjualan produk. Instagram adds merupakan fitur baru yang hadir setelah instagram diakusisi oleh Facebook sejak tahun 2012. Prinsip dari instagram adds adalah menggunakan cookies, ketika viewer meng-like salah satu konten maka adds tersebut akan muncul di laman instagram pengguna instagram lain pada fitur explore. 


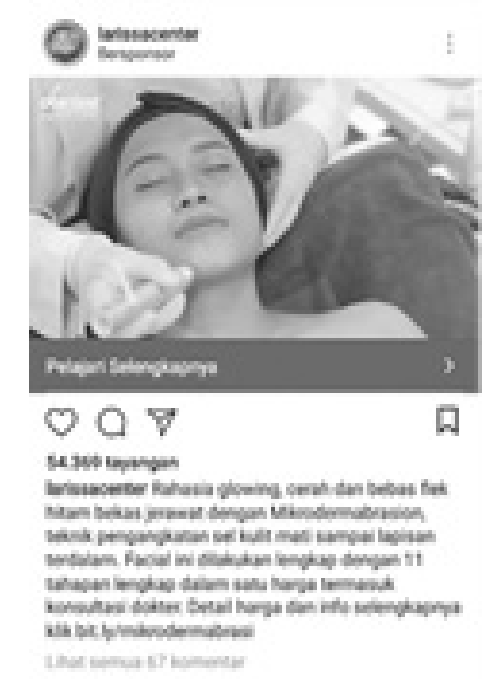

Gambar 4. Instagram Adds @larissacenter

Jenis penelitian yang digunakan dalam penelitian ini adalah penelitian kuantitatif deskriptif. Data yang dicari dalam penelitian ini yaitu data mengenai efektivitas iklan dengan metode CRI (Customer Response Index) iklan Larissa Aesthetic Center pada akun instagram @larissacenter. Customer Response Index merupakan hasil perkalian antara awareness (kesadaran), comprehend (pemahaman konsumen), interest (ketertarikan), intentions (maksud untuk membeli) dan action (bertindak membeli). CRI menampilkan proses akhir berupa pembelian yang berawal dari munculnya kesadaran akan sebuah iklan.

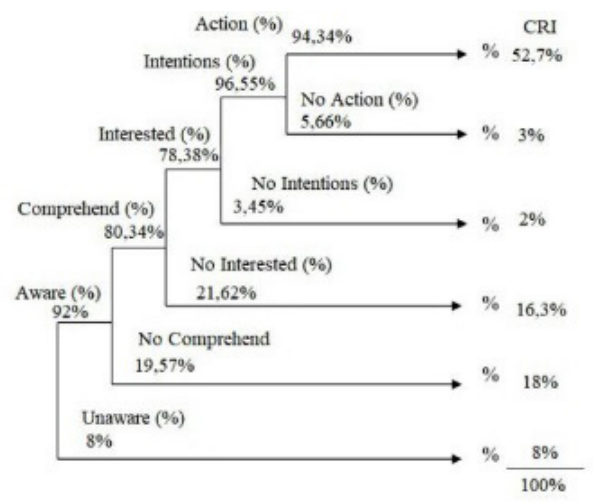

Gambar 5. Hasil CRI Larissa Aesthetic Center

Hasil perhitungan data dari 100 responden dalam penelitian ini pada tahapan aware menunjukkan bahwa 92 responden atau dengan prosentase sebesar 92\% mengetahui merek Larissa Aesthetic Center sedangkan 8 responden atau dengan prosentase sebesar 8\% teridentifikasi dalam tahapan tidak mengetahui merek Larissa Aesthetic Center. Pada tahap comprehend atau pemahaman konsumen menunjukkan bahwa prosentase sebesar 80,34\% teridentifikasi telah memiliki pemahaman terhadap merek Larissa Aesthetic Center sedangkan prosentase sebesar 19,57\% teridentifikasi tidak memahami merek Larissa Aesthetic Center. Pada tahap interest prosentase sebesar 78,38\% teridentifikasi dalam tahapan telah tertarik dan prosentase sebesar 21,62\% teridentifikasi merasa tidak tertarik dengan merek Larissa Aesthetic Center. Pada tahap maksud untuk membeli atau intention prosentase sebesar $96,55 \%$ yang menyatakan keinginan untuk membeli produk terkait Larissa Aesthetic Center sedangkan prosentase sebesar 3,45\% menyatakan tidak memiliki keinginan untuk membeli produk. Pada tahap action prosentase sebesar 94,34\% teridentifikasi dalam tahapan action sedangkan yang belum teridentifikasi dalam tahapan action di prosentase sebesar 5,66\%. Dari hasil masing-masing indikator metode CRI maka diperoleh nilai efektivitas iklan @larissacenter sebagai media beriklan adalah:

$C R I=$ awareness $x$ comprehend $x$ interest $x$ intention $x$ action $=92 \% \times 80,34 \% \times 78,38 \% \times 96,55 \% \times 94,34 \%$ $=\mathbf{5 2 , 7 6 \%}$

Hasil dari nilai Customer Respons Index dipetakan ke rentang skala. Rentang skala tingkatan efektivitas iklan Larissa Aesthetic Center melalui instagram berada pada rentang skala nilai 33,00 - 66,00 : efektivitas iklan Larissa Aesthetic Center melalui instagram (52,76 \%) masuk ke dalam kategori cukup efektif. 


\section{KESIMPULAN}

Berdasarkan hasil perhitungan efektivitas dengan menggunakan metode $C R I$, prosentase yang dihasilkan adalah sebesar 52,76\%. Yang mana hasil tersebut dikatakan cukup efektif karena berada di rentang skala 34,00-66,00. Instagram dapat menjadi media iklan alternatif yang efisien, terjangkau, dapat menjangkau sasaran audiens yang lebih luas dan selain itu perusahaan dapat mendapatkan feedback langsung dari konsumen setelah menggunggah foto atau video dalam iklan atau ke beranda mereka dengan fitur 'like' dan 'comment'.

\section{DAFTAR PUSTAKA}

Buku :

Best, Roger J. 2012. Market-Based Management : Strategies For Growing Customer Value and Profitability 6 ed. New Jersey : Prentice Hall, 247.

Durianto,Darmadi, dkk.2003. Invasi Pasar dengan Iklan yang efektif Strategi, Program dan Teknik Pengukuran. Jakarta: Gramedia, 10.

Narullah, Rulli. 2013. Cyber Media. Yogyakarta : Idea Press, 17.

Moriaty, Sandra, Nancy Mitchell dan William Wells. 2011. Advertising edisi kedelapan. Jakarta : Kencana, 30.

Tjiptono, Fandy. 2015. Strategi Pemasaran Promosi Iklan Media Sosial Kompetitif Market edisi 4. Yogyakarta : CV Andi Offset, 394.

Yosal, Irianta. 2005. Media Relations Konsep, Pendekatan dan Publik, Bandung : Simbiosa Rekatama Media, 118.

Website :

https://ataboks.katadata.co.id/datapublish/2018/02/09/berapa-pengguna-instagram-dari-indonesia (diakses pada 05 April 2018)

http://larissa.co.id/about diakses pada 22 Mei 2018

https://www.instagram.com/larissacenter/ diakses pada 22 Mei 2018

Jurnal :

Aiwan, Tania Yosephine.2013. Efektivitas Pesan Iklan Televisi Tresemme Menggunakan Customer Response Index (CRI) Pada Perempuan di Surabaya. Jurnal E-Komunikasi Program Studi Komunikasi Universitas Kristen Petra Surabaya Vol1 no 2 Tahun 2013

Ernestivita, Gesty. 2017. Mengukur Efektivitas Tagline Iklan Televisi Minuman Ringan Teh Botol Sosro Dengan Metode Customer Response Index (CRI). EkoNika 1 Vol 2 September 2017: 112-126 